\title{
Contribution of teachers' perceptions about the effectiveness of principal leadership and interpersonal communication on school climate through emotional intelligence
}

\author{
Imam Rahmadani *, Juhriyansyah Dalle, Ngadimun \\ Master Program of Education Management, Universitas Lambung Mangkurat, Banjarmasin 70123, \\ Indonesia
}

\section{Article history:}

Submission August 2020

Revised October 2020

Accepted October 2020

*Corresponding author:

E-mail:

imam.rahmadani24@gmail.com

\begin{abstract}
This study aims to analyze the Contribution of Teacher Perceptions About the Effectiveness of Principal Leadership and Interpersonal Communication on School Climate through Teacher Emotional Intelligence. This research uses quantitative descriptive methods. Sample 324 in Banjarmasin elementary schools. Data were extracted using a questionnaire that was valid and reliable and analyzed using Path Analysis. The results showed that: (1) There was a direct contribution between teachers 'perceptions of the effectiveness of the principal's leadership, interpersonal communication, emotional intelligence, and school climate (2) There was an indirect contribution between teachers' perceptions of the effectiveness of the principal's leadership, interpersonal communication through emotional intelligence as an intermediary variable in the climate of elementary schools in Banjarmasin City. This study concludes that significant results were obtained for all variables studied.
\end{abstract}

\section{Introduction}

The ideals of the intellectual life of the nation are still far from expectations. Educational outcomes at various levels are still far from the standard. This can be seen from several indicators, namely: 1) According to the World Economic Forum (WEF), In a report titled Global Human Capital Report 2017, which examines the quality of human resources in 130 countries based on several indicators used, Indonesia ranks 65th, the average quality of our human resources is still below other ASEAN countries, such as Singapore (11), Malaysia (33), Thailand (40), and the Philippines (50). 2) Based on data from the Organization for Economic Co-operation and Development (OECD) in 2015, which said that the quality of education in Indonesia was ranked 69 out of 76 countries, below Thailand (47) and Malaysia (52) even far compared to Vietnam in the country. position 12.3) World Bank Report 2018 that the competitiveness of human resources (HR) in Indonesia is still below that of other countries in the same region. This fact shows that education in Indonesia is still behind compared to other countries in the world. It can be concluded that the weaknesses of education in Indonesia are in the quality of education so that it affects the low human resources and competitiveness of the Indonesian population

The principal is the education component that plays the most important role in improving the quality of schools. The efficiency and effectiveness of the principal's leadership is the key to the success of a school (Aslamiah, 2011).

How to cite:

Rahmadani, I. (2020). Analysis of the effect of ICT education and training, professionalism and performance of elementary teachers on the quality of learninf in the KKG group in Telawang, Banjarmasin. Journal of K6 Education and Management, 3 (3), 295 - 302. doi: 10.11594/jk6em.03.03.02 
The harmonious relationship of school members with good communication from the principal is shown when communicating the tasks that must be carried out by the teacher, when giving new information, inviting, giving orders, organizing, moving, guiding, reprimanding, and others. Communication is an activity that is always carried out by everyone because communication is one of the human needs as social beings. Performance Effective communication can affect one's performance because communication provides a channel for the management process in providing information and building understanding (Suriansyah, 2014).

Good emotional intelligence is also very important for teachers to learn to respect, understand, understand, empathize and be able to respond appropriately how to handle students who have a wide range of characteristics and can have positive perceptions of the principal. In connection with this, Goleman (2016) states emotional intelligence also has an important role in someone because actuality alone cannot work as well as possible without emotional intelligence. This is in line with emotional intelligence according to Cooper (2002), namely the ability to perceive emotional sensitivity as a source of human energy, connection, and influence information. This is made clear by the results of research conducted by Novitasari (2020) which concluded that there is a relationship between interpersonal communication with emotional intelligence.

Besides, Edwardin (2006) also states that emotionally intelligent teachers can understand how emotions occur, can regulate their emotions, reduce unproductive emotions that become obstacles in cooperation, and can establish a harmonious social life with fellow teachers, the community around the work environment, and the community where they live.

In addition to emotional intelligence, other factors that contribute to performance are communication which is the main factor in improving work quality, because a job is inseparable from the adequacy and accuracy of information about work, attention to the needs of workers, complaints, and opportunities to interact intensively vertically and horizontally, which in the end it fosters both happy and unhappy feelings when working on a job (Suriansyah, 2014).

School leaders are those who know a lot about their assignments and who. determine the atmosphere for their school (Wahjosumidjo, 2010). Suriansyah and Ferdiana (2019) In his research, it was stated that there was a relationship between school climate and principal leadership. a conducive school climate reflects a harmonious and dynamic relationship between fellow school members, be it teachers, principals, students, parents, students, or school staff.

\section{Material and Methods}

Sample The study population was all teachers in Banjarmasin Elementary School. The research sample was 324 teachers in 137 schools select by Sampling using Simple Proportionate Random Sampling. Data collection using a questionnaire model that was tested for validity and reliability by choosing between one to five answers that best suit actual conditions. There are four questionnaires used in this study, namely the teacher's perception questionnaire about the effectiveness of the principal's leadership, interpersonal communication questionnaire, emotional intelligence questionnaire, and the school climate questionnaire. Following the conceptual relationship model between variables (Figure 1).

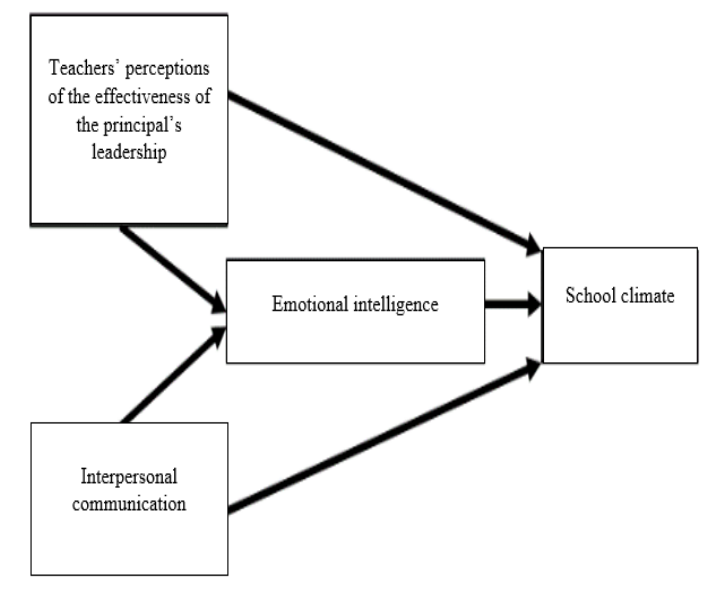

Figure 1. Research model 


\section{Results and Discussion}

It is Table 1 which includes the mean, standard deviation, and categories. The results of the classical assumptions test include residual normality data tests using the Kolmogorov-Smirnov one-sample method showing all the variables are normally distributed. Homogeneity test results indicate that all variables used are from the same population or homogeneous variance. The multicollinearity test results showed that the tolerance value of each variable was above 0.1 and the VIF value was below 10. After all the analysis requirements have been met, the next step is to analyze the results of the path analysis with a summary of the results in Table 2.

Table 1. Mean, standard deviation, and categories of research variables (SPSS 25)

\begin{tabular}{lccc}
\hline \multirow{2}{*}{ Variable } & \multicolumn{3}{c}{ Descriptive } \\
\cline { 2 - 4 } & Mean & Standard Deviation & Category \\
\hline Contribution of Teachers' Perceptions About the & 209.99 & 4.431 & Very High \\
Effectiveness of Principal Leadership & 175.94 & 4.304 & High \\
\hline Interpersonal Communication & 158.87 & 4.293 & High \\
\hline Emotional Intelligence & 101.93 & 4.415 & High \\
\hline School Climate &
\end{tabular}

Table 2. Results of path analysis in structure model 1

\begin{tabular}{|c|c|c|c|c|c|c|}
\hline Variable & $\begin{array}{c}\text { Path } \\
\text { coefficient }\end{array}$ & $t$ & Sig & $R^{2}$ & $F$ & Sig \\
\hline $\begin{array}{l}\text { Contribution of Teachers' } \\
\text { Perceptions About the Effectiveness } \\
\text { of Principal Leadership }\end{array}$ & 0.175 & 2.598 & 0.010 & \multirow[t]{2}{*}{0.112} & \multirow[t]{2}{*}{20.222} & \multirow[t]{2}{*}{0.000} \\
\hline Interpersonal Communication & 0.415 & 6.154 & 0.000 & & & \\
\hline
\end{tabular}

Table 3. Results of path analysis in structure model 2

\begin{tabular}{|c|c|c|c|c|c|c|}
\hline Variable & $\begin{array}{c}\text { Path } \\
\text { coefficient }\end{array}$ & $t$ & Sig & $R^{2}$ & $\boldsymbol{F}$ & Sig \\
\hline $\begin{array}{l}\text { Contribution of Teachers' } \\
\text { Perceptions About the Effectiveness } \\
\text { of Principal Leadership }\end{array}$ & 0.219 & 3.156 & 0.002 & \multirow{3}{*}{0.084} & \multirow{3}{*}{9.807} & \multirow{3}{*}{0.000} \\
\hline Interpersonal Communication & 0.392 & 5.410 & 0.000 & & & \\
\hline Emotional Intelligence & 0.091 & 1.602 & 0.010 & & & \\
\hline
\end{tabular}

Table 4. Summary of decisions on hypothesis testing $\mathrm{H}_{1}, \mathrm{H}_{2}, \mathrm{H}_{3}, \mathrm{H}_{4}$, and $\mathrm{H}_{5}$

\begin{tabular}{lcc}
\hline Hypotesis & $\boldsymbol{p}$ & Decision \\
\hline $\begin{array}{l}\mathrm{H}_{1}: \text { There is a contribution of the teacher's perception of the } \\
\text { effectiveness of the principal's leadership on the emotional } \\
\text { intelligence of the teacher }\end{array}$ & 0.010 & Accepted \\
\hline $\begin{array}{l}\mathrm{H}_{2}: \text { There is a contribution of teachers' perceptions about the } \\
\text { effectiveness of the principal's leadership on the school climate }\end{array}$ & 0.002 & Accepted \\
$\begin{array}{l}\mathrm{H}_{3}: \text { There is a contribution of interpersonal communication to } \\
\text { the emotional intelligence of teachers }\end{array}$ & 0.000 & Accepted \\
\hline $\begin{array}{l}\mathrm{H}_{4}: \text { There is a contribution of interpersonal communication to } \\
\text { the school climate }\end{array}$ & 0.000 & Accepted \\
\hline $\begin{array}{l}\mathrm{H}_{5}: \text { There is a contribution of the teacher's emotional } \\
\text { intelligence to the school climate }\end{array}$ & 0.010 & Accepted \\
\hline
\end{tabular}


Table 5 Summary of $\mathrm{H}_{6}$ and $\mathrm{H}_{7}$ Hypothesis Testing Decisions

\begin{tabular}{llcl} 
& \multicolumn{1}{c}{ Hypothesis } & \multirow{2}{*}{ Path Coefficient } & \multirow{2}{*}{ Decision } \\
\cline { 2 - 3 } & Direct & Indirect & \\
\hline $\begin{array}{l}\mathrm{H}_{6}: \text { There is an indirect contribution of } \\
\text { teachers' perceptions about the effectiveness of } \\
\begin{array}{l}\text { the principal's leadership towards the school } \\
\text { climate through the teacher's emotional }\end{array}\end{array}$ & 0.219 & 0.234 & Accepted \\
intelligence & & & \\
\hline $\begin{array}{l}\mathrm{H}_{7}: \text { There is an indirect contribution of } \\
\text { interpersonal communication to the school } \\
\text { climate through the emotional intelligence of } \\
\text { teachers }\end{array}$ & 0.392 & 0.430 & Accepted \\
\hline
\end{tabular}

There is a contribution of the teacher's perception of the effectiveness of the principa's leadership on the emotional intelligence of the teacher

The results of the path coefficient analysis for teacher perception variables about the effectiveness of principals' leadership on the emotional intelligence of teachers have a significance value of $0.010<0.05$ so it can be concluded that the teacher's perception of the effectiveness of the principal's leadership has a significant contribution to the emotional intelligence of teachers, thus Ho stated rejected. This is following the opinion of Bimo Walgito (2001), which states that several things can affect human perception, namely: a) the state of the stimulus, in this case, a human being who will be perceived; b) the social situation or circumstances that act as the background of the stimulus; and c) the condition of the person perceiving. It means that perception is influenced by a person's emotional intelligence abilities. The better a person's emotional intelligence, the better his perception of others.

Salovey and Mayer (2004) stated that emotional intelligence is the ability of a person to monitor their feelings and emotions both in themselves and in others. He will be able to distinguish between the two things and then use the information to guide his thoughts and actions. In this case, it means that the ability of a teacher's emotional intelligence will affect their perceptions of others, in this case to the principal. This opinion is also supported by Turnip's (2019) research that emotional intelligence affects teacher perceptions, and
Zhaelani (2018) also states that there is a significant influence between emotional intelligence and perception.

\section{There is a contribution of teacher's percep- tion about the effectiveness of the principal's leadership on the school climate.}

The results of the path coefficient analysis for teacher perception variables about the effectiveness of school principals 'leadership on the state primary school climate have a significance value of $0.002<0.05$. It can be concluded that the teacher's perception variables regarding the effectiveness of school principals' leadership have a significant contribution to the school climate, thus Ho states rejected.

Teachers' perceptions about the effectiveness of the principal's leadership on school success. Organizational climate is a character characterized by human relations with the organization and the relationship of leadership and followers. Intermediary relationships are determined by interactions between goals, goals, formal structures, management processes, leadership styles and subordinate relationships (Mullins, 2010).

This finding also agrees with the results of Azhari's (2020) study that there is a positive and significant relationship between the variable of principal leadership effectiveness and organizational climate. This result is also supported by Suhardi's research (2020) which states that the more conducive organizational climate and the increasing effectiveness of leadership. This opinion is also supported by research by Masnawati (2018). Leadership has 
a positive direct effect on organizational climate, which means that the right leadership can help form a conducive organizational climate.

\section{There is a contribution of interpersonal com- munication to the emotional intelligence of teachers.}

The results of the path coefficient analysis for interpersonal communication variables to the emotional intelligence of teachers have a significance value of $0,000<0.05$, it can be concluded that interpersonal communication has a significant contribution to the emotional intelligence of teachers, thus Ho is declared rejected.

Communication is the delivery and reception of messages (Sutrisno, 2010) and according to Muhammad (2009) interpersonal communication is the process of communicating information between a person with the least related to others or that can be done with feedback. This finding complements the research conducted by Sari (2019) who collected interpersonal communication that affects one's logistical intelligence. Therefore, teachers who have good interpersonal communication will have the emotional intelligence that will improve intelligence and relationships in the school environment and outside of school.

\section{There is a contribution of interpersonal com- munication to the school climate}

The results of the path coefficient analysis for interpersonal communication variables on the climate of public elementary schools in the city of Banjarmasin have a significance value of $0,000<0.05$, it can be concluded that interpersonal communication has a significant contribution to the school climate, thus Ho is declared rejected.

This means that good communication will produce a good school climate. This is consistent with the purpose of interpersonal communication, one of which is maintaining relationships (Devito, 2017). This opinion is also supported by Suranto (2011) that the character of interpersonal communication is that the two parties who communicate depend on one another. This is in line with Taguiri and
Litwin (1988) which defines organizational climate as a quality of the internal environment of an organization experienced by its members which affect their behavior and can be described by the values of organizational characteristics. It can be concluded that interpersonal communication affects a climate in the school.

\section{There is a contribution of the teacher's emotional intelligence to the school climate}

The results of the path coefficient analysis for the variable emotional intelligence of teachers to the climate of public elementary schools in Banjarmasin City have a significance value of $0.010<0.05$, it can be concluded that the emotional intelligence of teachers has a significant contribution to the school climate, thus Ho is declared rejected.

Teacher emotional intelligence has an important role in shaping the school climate, emotional intelligence makes teachers more optimally to better recognize themselves and the work environment so that teachers can express emotions appropriately within the school environment and provide motivation to themselves to be able to survive in dealing with problems in the school environment. According to Salovey and Mayer (2004) suggested emotional intelligence is the ability of a person to monitor his feelings and emotions both on himself and others. He will be able to distinguish these two things, then use that information to guide his thoughts and actions. This opinion is also supported by Turnip's research (2019) which states that teacher perceptions influence emotional intelligence, and Zhaelani (2018) also mentions that there is a significant influence between perception and emotional intelligence.

Teachers with high emotional intelligence will be able to know, feel, understand, and effectively apply emotional sensitivity to all school members. A teacher if his emotions are out of control, his ability to handle reactions will deteriorate so that in his view of the principal will be less good. His views on the principal are subjective and not objective because of those who judge according to his feelings. Emotional intelligence is what influences how to influence the views or 
perceptions of the principal's leadership because in it there is an attitude of understanding others. This opinion is also supported by the opinion of Hoy and Miskell (1982) stating that the school climate or environment is the final product of the interaction between groups of students in schools, teachers, and administrative staff (administrators) who work to achieve a balance between organizational dimensions (school) with individual dimensions.

There is an indirect contribution of teachers' perceptions about the effectiveness of the principal's leadership towards the school climate through the teacher's emotional intelligence

Based on the table it is known that the value of direct influence is 0.219 and indirect effect is 0.234 which means that the value of the indirect effect is greater than the direct effect, so it can be concluded that there is an indirect contribution of teachers' perceptions about the effectiveness of the principal's leadership on the school climate through teacher emotional intelligence, thus Ho was declared rejected. In making one's perception influenced by the environment or here the school climate and the ability of the senses here is emotional intelligence. This means that there is a link between school climate, emotional intelligence, and teacher perceptions.

The results of this research data are also supported by the expert opinion of Goleman (2002) which explains that emotional intelligence is a series of personal, emotional, and social abilities that can affect a person's ability to succeed in coping with environmental demands and pressures. According to Goleman (2002), someone who experiences emotional deterioration has problems in terms of attention and thinking so that he is unable to focus attention, acts without thinking, and is unable to calm the mind. This means that there is a greater influence that affects the perceptions of a teacher when it is related to school climate and emotional intelligence. This is also under the theory of attitude-forming components proposed by Azwar (2006), namely the affective component related to feelings and emotions which contains the direction and intensity of one's assessment of the object of attitude, which is an indicator of emotional intelligence.

Teachers with high emotional intelligence will be able to know, feel, understand, and effectively apply emotional sensitivity to all school members. A teacher if his emotions are out of control, his ability to handle reactions will deteriorate so that in his view of the principal will be less good. His view of the principal is subjective and not objective because the judge is based on his feelings. Emotional intelligence is what influences how to influence the views or perceptions of the principal's leadership because in it there is an attitude of understanding others. This opinion is also supported by the opinion of Hoy and Miskell (1982) which states that the climate or school environment is the final product of interactions between groups of students in schools, teachers, and administrative staff (administrators) who work to achieve a balance between organizational dimensions ( school) with individual dimensions.

The results of this data are supported by research by Christopher (2019) that there is a strong relationship between school climate and emotional intelligence. Tutriyanto (2015) in the research results there is an influence between school climate and emotional intelligence. This research is also in line with research conducted by Ngatmini (2015) that there is a positive and meaningful relationship between teacher perceptions and emotional intelligence.

\section{There is an indirect contribution of interpersonal communication to the school climate through the emotional intelligence of teachers}

Based on the table above it is known that the value of the direct effect of 0.392 and the indirect effect of 0.43 which means that the value of the indirect effect is greater than the direct effect, it can be concluded that there is an indirect contribution of interpersonal communication to the school climate through teacher emotional intelligence, with thus Ho was declared rejected. 
Good interpersonal communication will make a good school climate, but communication that is accompanied by good emotional intelligence will produce a better school climate. According to Muhammad (2009), interpersonal communication is the process of exchanging information between a person with at least one other person or usually between two people who can be directly identified. Meanwhile, Trenholm and Jensen interpret interpersonal communication as communication between two people that goes on face to face (dyadic communication). The nature of dyadic communication is: spontaneous and informal, with maximum mutual acceptance, and participants have a flexible role (Suranto, 2011).

Teachers' perceptions about the effectiveness of the principal's leadership, interpersonal communication, and good emotional intelligence will affect the school climate to be good.

\section{Conclusion and Recommendation}

The results showed as follows; (1) There is a the teacher's perception of the effectiveness of the principal's leadership on the emotional intelligence of the teacher; (2) There is the teacher's perception of the effectiveness of the principal's leadership on the school climate; (3) There is an interpersonal communication to the emotional intelligence of teachers; (4) There is an interpersonal communication to the school climate; (5) There is a teachers' emotional intelligence to the school climate; (6) There is a contribution of teachers' perceptions about the effectiveness of the principal's leadership on the school climate through the teacher's emotional intelligence; (7) There is a contribution of interpersonal communication to the school climate through the emotional intelligence of teachers.

Research conclusions; (1) a description of teacher perceptions about the effectiveness of the principal's leadership, interpersonal communication, emotional intelligence, and the school climate average on a high score, (2) there is a contribution of the teacher's perception of the effectiveness of the principal's leadership, interpersonal communication, emotional intelligence, to the school climate of Public Elementary School in Banjarmasin City.

\section{Acknowledgment}

Our gratitude and appreciation extend to all parties involved and contributed in completing this research

\section{References}

Aslamiah, A. (2011). Leadership of the Principal in Improving the Quality of Education. AL JAMI-Jurnal Ilmiah Keagamaan, Pendidikan \& Dakwah, 7(1)

Azhari, M. (2020). The Relationship Between Leadership Effectiveness of School Principals, Organizational Climate and Work Productivity of Public Elementary School Teachers in Tenggarong District. Pendas Mahakam: Jurnal Pendidikan Dasar, 4(1), 55-67.

Azwar. (2006). Maintaining Quality Health Services Application of Circle Principles. Solution to problem. Jakarta: Pustaka Sinar Harapan

Bimo, W. (2001). Social Psychology. Yogyakarta: Andi Offset

Christopher, H. G. (2019). Relationship between School Climate and Students' Emotional Intelligence. Jurnal Review Pendidikan dan Pengajaran, 2(1), 215220.

Cooper, R.K. (2002). Emotional Intelligence in Leadership and Organization; Language expert Alex Tri Kontojono Widodo. Jakarta: PT Gramedia

DeVito, J A. (2007). The Interpersonal Communication Book, 11th edition. Pearson Educations, Inc

Edwardin, L. T. (2006). Analysis of Communication Competence, Emotional Intelligence, and Organizational Culture on Employee Performance (Study at PT POS Indonesia (Persero) in Semarang City). Program Pascasarjana Universitas Diponegoro Semarang

Ferdiana, R., \& Suriansyah, A. (2019). The Relationship of Principal Leadership and Organizational Climate on Motivation and Performance of Teacher in Primary School. Journal of K6, Education and Management, 2(3), 246-251.

Goleman. (2002). Leadership Based on Emotional Intelligence; Language expert Susi Purwoko. Jakarta: PT. Gramedia Pustaka Utama.

Goleman, D. (2016). Working With Emotional Intelligence: Emotional Intelligence To Reach The Top Of Achievement. Jakarta: PT Gramedia Pustaka Utama.

Hoy Wayne, K and Miskel, CG. (1982). Educational Administration. New York: Graw-Hill Co.

Masnawati, N. (2018). The Influence of Leadership and Organizational Climate on Rewards in Public Elementary Schools, Kebon Jeruk and Cengkareng Districts. Journal of Educational Management, 9(2), 101-110. 
Muhammad. (2009). Organizational Communication. Jakarta: Bumi Aksara.

Mullins, Laurie J., (2010). Essentials of Organisational Behaviour 9 edition. Harlaow: Pearson Education Limited.

Ngatmini, M. (2015). The Influence of Teacher Perceptions of the Principal's Emotional Intelligence on Teacher Performance at State High Schools in Medan City. Jurnal Pendidikan Teknologi Dan Kejuruan, 17(1), 6-10.

Salovey P dan Mayer J. (2004). Test and Sharpen the EQ. Jakarta Harmoni.

Sari, A. N., \& Suriansyah, A. (2019). The Contribution of Emotional Intelligence and Interpersonal Communication on Teacher Performance Through Job Satisfaction. Journal of K6, Education and Management, 2(3), 229-233.

Suhardi, M. (2020). Relationship between Organizational Climate and Leadership Effectiveness with the Performance of Private Junior High School Teachers in Jonggat District, Central Lombok. Teaching And Learning Journal of Mandalika (Teacher),1(1), 27-31.

Suranto. (2011). Interpersonal Communication. Yogyakarta: Graha Ilmu.
Suriansyah, A. (2014). School Cultural Relationships, Communication, and Work Commitment to Public Elementary School Teachers. Jurnal Cakrawala Pendidikan., 8(7)1-10.

Sutrisno, E. (2010). Organizational culture. Jakarta: Prenada Media Group.

Tagiuri, R. \& Litwin G. (1988). Organizational Climate: Expectations of a Concept. Boston: Harvard University Press

Tutriyanto. (2015). The effect of school climate and emotional intelligence on learning achievement. Jurnal Penelitian dan Pendidikan IPS, 9(2), 8-13.

Turnip, H. (2019). Pengaruh Kecerdasan Emosional, Persepsi Guru Tentang Komunikasi Interpersonal Kepala Sekolah, dan Kompensasi Terhadap Komitmen Afektif Guru TK Kecamatan Medan Perjuangan (Doctoral dissertation, UNIMED).

Zhaelani, T. (2018). The Effect of Emotional Intelligence and Perceptions of Permissive Parenting on Learning Motivation of Class IV Elementary School Students. Basic Education, $7(14), 1-332$ 